\title{
LUDWIG VAN BEETHOVEN
}

\section{Sylvia Townsend Warner}

(a review of The Unconscious Beethoven by Ernest

Newman, and Beethoven by Harvey Grace, in Time and Tide, March 25th, 1927)

Like a very superb bramble-patch the ruling and noble families of Germany and Austria tangled and extended, struck root, branched again, blossomed and cross-fertilised over the Europe of the Rhine and the Danube. So when a swarthy, stocky, red-faced young man from Bonn arrived in Vienna in the November of 1792 , with a certain reputation as a keyboard virtuoso, some aptitude as a composer, an album containing a flattering inscription by Count Waldstein, and a promise of financial support - not fulfilled, though; the French Revolutionary Army put a spoke in that wheel - from the Elector of Cologne, he could be fairly sure of finding patrons, employment and (what a young man wants most) attention. This was not his first experience of Vienna. He had visited the city five years before, had met Mozart and improvised before him. Now, Mozart was dead, and the untimeliness of his death emphasised the fact that Haydn was sixty-one. People were looking round for a new composer. They were to get him.

But there is no reason for that rather menacing cadence, for indeed they were delighted to do so. Beethoven's case gives a rude jolt to the convention that a great composer must inevitably be slighted by a generation of deaf adders. From the first year in Vienna he was honoured, sought-after and 
well-paid. His concerts were crowded, he made friends almost as fast as he could be disillusioned in them, and publishers queued up for his new works. It is sometimes said that the fickle Viennese public neglected him in his later years. This is not true. The fickle portion of the Viennese public, virtuoso-gapers, turned their attention elsewhere when deafness compelled him to give up his career as a performer; but the true music-lovers were true to the end. It is a testimony to the worth of their constancy that the late string quartets were attentively and appreciatively received (op. 127 was 'so much in request among the most celebrated players of Vienna that I (Beethoven) have granted it to some of them for their benefit'), and that with the exception of the Grosse Fuge, which was demurred at on grounds of technical difficulty, there was none of that boggling and bunkum which afterwards made 'Beethoven's last manner' such a word of fear.

But for all this, I suppose there was never a more distressful genius, and certainly never one so self-tormenting. Ten years after his arrival in Vienna, years of success, comparative freedom from rumpusses and untrammelled musical development (and there can be no satisfaction to the artist anywhere approaching the satisfaction of feeling himself go from strength to strength) Beethoven was writing in the Heiligenstadt Testament 'Providence, let me have at last just one pure day of joy; it is so long since true joy. resounded in my heart.'

He had already had attacks of deafness. His fears and selfpity were acute, his distress frantic. But those who pity Beethoven for his deafness should pity him accurately. In his letters and diaries he bewails that deafness will cut him off from his fellows, from an active musical life, from the outer world; not from his music, which was within him.

Mr. Newman in The Unconscious Beethoven - a study so luminous, concise, sympathetic and level-headed that it should become a classic, not only in Beethoven literature, but in the difficult craft of writing of music - treats of Beethoven as an extreme example of that welling-up from the unconscious mind which is called inspiration, in that 'in his 
greatest music head-work was carried on at the same level of incandescence as inspiration.' The truth of this saying must be appreciated if one calls to mind that most characteristic, nonmusical quality in Beethoven's music, the impression it gives of intense sincerity and integrity. Even when the music seems to be saying nothing in particular, or something rather foolish, there can be no doubt, for the hearer, that whatsoever is said, is meant. It is significant that it comes natural to speak of his music saying something. At its remotest and most austere it is not abstract but extract music, it is Beethoven speaking to us in his native tongue.

But I would go further. It seems to me that this incandescence has fused the whole man, and that Beethoven's worldly life, so incompetent, so fretful and perturbed, and apparently so utterly at variance with the power, the constancy and deliberate purpose of his creative life, was but a reverse, was the dark side of the moon. One reads the letters about his nephew's upbringing and they are so fussy and so teasing that the exclamation 'Old Granny!' rises to one's lips. And one turns to the letters about proof-corrections and finds the same fuss, the insistence upon jots and tittles. But one has half-circled the moon meanwhile, a solicitude which is misapplied to Carl's underwear is not misapplied to op.132. Again, the vacillations and dilly-dolly which preceded the 1824 concert can be oddly paralleled in the eighteen versions of the opening of Florestan's Aria. Lodgings and servants were discarded as ruthlessly as a superfluous quaver or a modulation which belied his true thought. Even that suspicion, that dreadful hankering to discover a fault in a friend which is the most painful trait in the letters, becomes in the scrutiny and revision of his creations the just exigence of one who is driving in rivets for eternity. The faculty for selftormenting made him what he was, both as man and musician.

It must have tormented others too. His friends had a good deal to put up with. Yet they endured his rude speeches, the 'Ah coom fra' Yorkshire' airs of his early manhood, his violent temper and his table-manners, his superhuman clumsiness, his puns, his priggishness (he was a sexual prig), 
even the infirmities and miseries of his later years; and endured them, as far as one can see, not because there was such greatness in his music, but because there was something to love in the man. He, too, loved his fellows and none the less sincerely because he could not get on with them. He found it easier to get on with nature. He liked sitting under trees, 'that splendid May rain,' wandering about in rough weather. Five years before his death he succeeded in getting himself arrested as a tramp. On the day of his death, as he lay unconscious, there was a violent clap of thunder, such as sometimes comes with a March snowstorm. He looked up. He seems to have heard that, though he had never heard the drums leap out in the Scherzo of the Ninth Symphony. 